\title{
Legislative Changes in the Environmental Impact Assessment act in the Slovak Republic
}

\author{
Michal Maslen* \\ * JUDr. Michal Maslen, PhD., senior lecturer, Department of Administrative Law, Environmental Law and Financial Law, Faculty of \\ Law, University of Trnava. His main fields of research are: administrative offences and responsibility, principles of administration, good \\ administration and administrative procedure. (e-mail: michal.maslen@truni.sk) \\ Abstract: The study is dealing with the implementation of the EIA Directive in the Slovak Republic, primarily focused on the participation of \\ public in environmental proceedings. The case law presented a special approach on this field - partially which - leaded to new ways of \\ interpretation of normative rules. \\ Keywords: environmental law; right to a favorable environment; right to a judicial protection; public interest; public participation
}

The Government of the Slovak Republic with its resolution no. 330/2014 of July $2^{\text {nd }} 2014$ approved a draft law amending and supplementing the Act no. 24/2006 Coll. on the environmental impact assessment. The Prime Minister of the Slovak Republic submitted the draft law to the National Council of the Slovak Republic on July $16^{\text {th }} 2014$. This proposition was adopted on October $14^{\text {th }} 2014$.

The mentioned governmental proposition brought changes and amendments made within the applicable Act no. 24/2006 Coll. This amendment represents the reaction of the Slovak Republic responding to the allegations of the European Commission in the framework of the so-called 'infringement proceeding' according to the Article 258 of the Treaty on the Functioning of the European Union. The breach of the obligation to apply the European Law was formally notified to the Slovak Republic by the European Commission on March $21^{\text {st }} 2013$ through the Letter no. 'C (2013)1558'.

According to the opinion of the European Commission, the main shortcoming of the previously valid Act no. 24/2006 Coll. was the insufficient connection of the process of the environmental impact assessment of the proposed activities with the subsequent proceedings of permission.

The European Commission criticized the Slovak Republic for the lack of implementation of Articles 6,7 and 9 of the Environmental Impact Assessment Directive. The abovementioned Directive provides in Article 6 the obligation of the member States to take the necessary measures to ensure that the institutions to which powers in the environmental field the project can relate, shall express their statement on the information supplied by the developer and the application for permission. This article of EIA Directive also established the obligation to inform the public early in the environmental decision-making and at the latest as soon as it can reasonably provide information either by public notices or other appropriate means such as electronic media where available, on the decision-making matters defined by this provision of the EIA Directive. At the same time, this provision requires from the Member States to ensure the access of the public concerned to the mentioned group of information in due time. Article 7 of the EIA Directive governs the cases in which the assessed project could most likely have significant impact on the environment of another Member State. Article 9 of the EIA Directive lays down the conditions and extent of providing the information to public about the granting or refusal of permission.

The EIA Directive is an important tool that enables to enforce the requirements of environmental protection into the design of construction projects. The meaning of the process of environmental impacts assessment lies in the fact that this procedure ensures that the consequences on the environment of the construction projects shall be assessed and taken into account before a competent authority of a Member State shall issue a decision permitting the project. The purpose of the EIA Directive includes the effort to ensure that projects likely to have significant impact on the environment shall be properly assessed prior to the permission.

The Slovak case law has presented a special approach to the right to a favorable environment and to the right to a judicial protection in the field of environmental impact assessment before.

The civic association 'G. S.' has filed an action against the unlawful intervention to the right to a favorable environment under the Article 44 of the Constitution of the Slovak Republic and under the Article 27 of the Act no. 24/2006 Coll. to the Supreme Court of the Slovak Republic.1 In the opinion of the mentioned civic association the essence of this intervention should lie in the fact that the Ministry of Environment of the Slovak Republic nominated people with biased professional qualification to prepare the expertise of the proposed activities in accordance with the Article 36 of the Act no. 24/2006 Coll. 2 
The Ministry of Environment of the Slovak Republic argued that the Article 27 of the Act no. 24/2006 Coll. does not create an independent right to a favorable environment of the non-governmental organization promoting the environmental protection. This article establishes the state that allows real exercise of the procedural rights of the party of the administrative proceeding, respectively the public concerned in the process according to the Act no. 24/2006 Coll. The Supreme Court of the Slovak Republic considered the relation between the designated qualified person and the intervention to the right to a favorable environment.

The purpose of the proceeding on the protection against the unlawful intervention caused by the public authority is to provide the judicial protection to the natural or legal person who claims to be disadvantaged in their rights and legitimate interests through the unlawful intervention of the public administration, which is not a decision, and at the same time this action was aimed against this natural or legal person or it was enforced as a result against this person.

The Supreme Court of the Slovak Republic focused on the fact, whether the civic association was entitled to bring an action against the unlawful intervention to the Supreme Court of the Slovak Republic. It concluded, that the civic association has demanded protection of individual rights against unlawful intervention by the public administration in proceedings according to Act no. 24/2006 Coll.

The dispute of the case was the assessment of the operation of a nuclear power plan. That is why the Supreme Court of the Slovak Republic did not automatically exclude the fact that its operation may have had an impact on the individual rights of the public concerned. Such fundamental rights of natural persons as their right to life or the right to property may have been affected. These rights may have a connection to the right to a favorable environment under Article 44 of the Constitution of the Slovak Republic as well. The object of the activities of the mentioned civic association was the environmental protection. The civic association brought together the individuals whose premise was the protection of public subjective right - the right to a favorable environment and the protection of other fundamental rights guaranteed by the Constitution - the right to life and the right to property. In this case the civic association met the conditions of the Article 27 of the Act no. 24/2006 Coll. 3 The case law in this case stated that the civic association helped the individuals to perform their right to a favorable environment. Therefore it has concluded that the civic association was entitled to bring an action for the protection against the unlawful intervention by the public authority. However, the key issue was to assess whether the designation of the objected qualified person filled up the characteristics of the unlawful intervention. The case law considers the intervention to be unlawful, if it directly intervenes in the subjective public rights - e. g. violation of the right to life, violation of the personal liberty, violation of the right to property, violation of the right to inviolability of the home and such. Either the civic association did not show a causal link between the claimed partiality of the expertise and the environmental impact assessment process.

Since January $1^{\text {st }} 2015$ the participation of the public concerned in the proceedings regulate the Articles 24 and 25 of the Act no. 24/2006 Coll. Section 1 of the Article 24 of this Act defines the obligation of the competent authority to inform the public about the facts established by law.

Subsequently, section 2 of the Article 24 of Act no. 24/2006 Coll. regulates the position of the participant of the public concerned in the proceedings established in the third part of Act no. 24/2006 Coll.

According to this provision, 'The public concerned has the status of a party in the proceedings referred to in the Third Part and subsequently the status of the participant in the proceeding on the permission of the proposed activity or its change if it applies the procedure under sections 3 or 4 if its participation in the proceedings does not already arise from the special regulations. Right of the public to a favorable environment, which has shown the interest in the proposed activity or its change through the procedure under sections 3 or 4, may be directly affected by the permission of the proposed activity or its change or by the subsequent performance of the proposed activity or its change.'

The public may show the interest in the proposed activity through the procedure under the Article 24 (3) of the Act no. 24/2006 Coll. If it does so, it automatically gains the position of the participant to the proceeding.

According to the Article 24 (3) of the Act no. 24/2006 Coll. 'The public shows the interest in the proposed activity or its amendment and in the proceeding of permission, when filing

a) a reasoned written opinion on the plan in accordance with the Article 23 (4)

b) a reasoned comment on the scope of the assessment of the proposed activity or its amendment according to the Article 30 (6)

c) a reasoned written opinion on the assessment report according to the Article 35 (2)

d) a reasoned written opinion on the notification of the amendment according to the Article 29 (9).'

The legal position of the participant to the proceedings guarantees several special procedural rights to the public under the Article 24 (4) of the Act no. 24/2006 Coll. effective from January $1^{\text {st }} 2015$. According to this provision 'The public has a right to appeal against the decision on whether the proposed activity or its amendment shall be assessed under this 
Act (hereinafter referred to as 'the decision issued in the screening proceeding'), or appeal against the final statement even if it was not a participant to screening proceeding or to the proceedings on the issuance of the final statement or amendments to it. The date of receipt of the decision when making such an appeal shall be the fifteenth day of the publication of the decision issued in the screening proceeding according to the Article 29 (15) or the fifteenth day of the publication of a final statement by the competent authority according to the Article 37 (7). The public by filing the appeal shall also show the interest on the proposed activity and on proceeding permitting it.'

Since January $1^{\text {st }} 2015$ the legislator has included the legal position of the participant to the public concerned in the proceedings referred to in the Third Part of the Act no. 24/2006 Coll. to the Article 24 (2) of the Act no. 24/2006 Coll. According to this provision, Right of the public to a favorable environment, which has shown the interest in the proposed activity or its change through the procedure under sections 3 or 4, may be directly affected by the permission of the proposed activity or its change or by the subsequent performance of the proposed activity or its change.'

In my opinion, this expression brings positive changes in the sense that it allows the public to step up against decisions issued under the provisions of the Act no. 24/2006 Coll. effective of January $1^{\text {st }} 2015$. Thus the Slovak legislator has ensured the transposition of the conditions of the Article 46 (2) 2 of the Constitution of the Slovak Republic, according to which 'who claims to have been deprived of his rights by the decisions of the public authority, may apply to the court to examine the legality of such a decision, unless the law stipulates otherwise. From the jurisdiction of the court the examination of decisions concerning fundamental rights and freedoms may not be excluded.' It can be said that in such case, the right to a favorable environment under the Article 44 of the Constitution of the Slovak Republic has in some way 'greened' the right to judicial protection under the Article 46 (2) of the Constitution of the Slovak Republic. The public concerned is in this way put in position, in which it is actively entitled to protect the right to a favorable environment. If the legislator presumes the direct connection between the intentions and proposed activities on one hand and the right to a favorable environment on the another hand, then it has also established the entitlement of the public concerned to file a constitutional complaint to the Constitutional Court of the Slovak Republic.

\section{References}

1 See: The judgment of the Supreme Court of the Slovak Republic of January $1^{\text {st }} 2011$, no. 8 Sžz 1/2010.

2 According to Article 36 (1) of Act no. 24/2006 Coll. effective in the year 2010, "Expertise on the proposed activity may be prepared only by a natural or a legal person who is professionally qualified according to Article 61 and designated competent authorities. A person who has participated in the preparation of the plan or in the assessment report on the activity cannot take part in the process of the preparation of the expertise. Other professionally qualified persons registered under special regulations may also participate in the process of the preparation of the expertise, if it arises from the nature of the impact of the proposed activity on the environment."

3 According to the Article 27 of the Act no. 24/2006 Coll. effective in 2010, "The non-governmental organization promoting the environmental protection, which submits a written statement to the intention of the proposed activity listed in Annex no. 8 according to Article 23 (4) has the status of a party within the integrated licensing, proceedings under the Road Act, Building Act, Aviation Act, Water Act, Railway Act, the Forests Act, the Nature and Landscape Protection Act and the authorization of Mining Activity Act. Such non-governmental organization is considered to be a subject whose right to a favorable environment may be affected by the decision. Non-governmental organization promoting environmental protection shall submit proof of registration to the competent authority and to the permitting authority together with submission of written observations on the proposed action plan." 